\title{
The Use of Booklet Media in Managing Bullying Behavior at the Lowest Class School
}

\author{
Wahyu Bagja Sulfemi ${ }^{1}$, Toni Heryadi ${ }^{2}$, Syarifuddin ${ }^{3}$ \\ \{wahyubagja@gmail.com ${ }^{1}$ \} \\ Sekolah Tinggi Keguruan dan Ilmu Pendidikan Muhammadiyah Bogor, Indonesia ${ }^{1}$ \\ Balai Bahasa Provinsi Jawa Barat, Indonesia ${ }^{2,3}$
}

\begin{abstract}
This study discusses the use of booklet media in overcoming bullying behaviour in low-grade elementary schools. This study uses a 4-D research and development (R\&D) method: Define, Design, Develop, and Disseminate. The study results obtained validation from experts in the material, media, and language showed that the booklet that was developed met the valid criteria and was suitable for use. The validation test results by elementary school teachers in Bogor Regency, which consisted of 30 booklet teachers, were very relevantto be used, did not need to be revised. A large-scale trial to grade 3 elementary school students in Bogor obtained that the booklet media was valid and suitable for use. The results of students' understanding of bullying at the beginning were shallow, amounting to only 31.03 percent while after learning given using the booklet media rose to $72.41 \%$. Thus this media booklet can be used as early prevention of bullying deviant behaviour. The use of booklet media with all its weaknesses and advantages is expected to positively influence the loss of bullying behaviour among students so that harmony is established within the school environment and realizing the school as a safe, comfortable, and pleasant place. Also, the school, as an educational institution, becomes a place to gain knowledge and develop one's maturity to show that he is intelligent rationally, emotionally, socially, and spiritually.
\end{abstract}

Keywords: Booklet, Bullying, Low grade, Elementary school

\section{Introduction}

The problem of students' behaviour for several years has become the concern of the government, schools, and society at large. The new public woke up and was shocked when the news about violence in students' circles became even more alarming. Violence in schools is increasingly diverse, including bullying cases by a student who is carried out in groups or individually against other students in school [1]. A school is a place that is safe, comfortable, and fun, as a place to gain knowledge as well as a place to produce the maturation of a person who can show that he is intelligent, rational, emotional, social, and spiritual [2], [3].

The phenomenon of bullying is no longer a new thing, especially in education at various levels, light, moderate, and severe. The mildest bullying cases can be intense when the bully feels prolonged hurt and harbour feelings of resentment towards someone that leads to death [4], [5]. In Indonesia, the word bullying is known as the word "bullying" which means challengingor difficult. After being given the adjunct of speech, it becomes "bullying" which means bullying, and exploiting or continuing acts of violence [6], [7]. 
The problem of bullying is increasingly worrying, as reported by the Indonesian Child Protection Commission (KPAI) that currently bullying is in the top rank according to public complaints from 2011 to August 2014. The Indonesian Child Protection Commission noted that there were 369 complaints related to bullying. Of the cases, about $25 \%$ came from the education sector, with 1,480 bullying cases, KPAI stated that bullying as a form of violence in schools beats student brawls, educational discrimination, and complaints against illegal payments [8], [9]. Research conducted by Arofa, et al., showed that the results of the study in 3 (three) major cities in Indonesia, namely: Yogyakarta, Surabaya, and Jakarta noted that students in SMP were $66.1 \%$ while students from SMA differed only slightly, namely $67.9 \%$, psychological bullying ranks first while verbal bullying ranks second [10].

The case of bullying deviant behaviour does not happen to junior and senior high school students only but has reached elementary school students, such as driving to grade 2 students of Elementary School 07 PagiKebayoran Lama Utara, South Jakarta. The bullying case comes from ridicule during drawing school activities to continue to abuse and make a student die. A similar case also happened to a grade 5 student at Bintara Jaya 2 State Elementary School, Keranji, West Bekasi. The incident occurred during class hours, and the homeroom teacher was leaving the classroom. A student was mistreated by 10 of his friends until he was injured [11].

Based on the various explanations above, bullying deviant behaviour must be stopped to reduce it because it is known that bullying hurts students' survival and even takes victims. Also, the problem of bullying causes stress to students, lack of self-confidence, loneliness, anxiety disorders, affecting social relations, even children who are excluded can withdraw from social relationships, resulting in students not having the opportunity to develop the social skills needed [12].

Another adverse effect is a decrease in enthusiasm for learning so that it results in poorlearning outcomes and learning achievement, especially for elementary school students who are in this low class, which will continue in the next gradeeven after the next level of education [13]. This age period is a short period of child development but a significant period in determining the next phase of life [14]. Therefore, all the potential that the child or students have needs to be encouraged so that the child's potential will develop optimally

Low-grade students in learning are very operational and concrete. They have unique characteristics [15], which are still dominated by egocentric nature so that they require understanding in interacting with their friends [16]. Thus, if the basic concept given is wrong, it will carry over to adulthood. In this phase, development is influenced by the environment [17], [18]. For this reason, low-grade elementary school children need attention and guidance, especially from various parties, including parents, schools, and teachers, mainly to prevent bullying deviant behaviour.

Various bullying problems that occur at school require a step and action through various learning media to be understood by students that teachers and parents can convey in preventing bullying behaviour as early as possible so that the school becomes a place to gain knowledge that is safe, comfortable and enjoyable, and the creation of educational goals to produce intelligent humans rationally, emotionally, socially and spiritually.

\section{Methods}

This research uses a development research method called Research and Development (R \& D) with a 4-D model. In developing booklet media through expert assessment or validation, two 
material experts, two media experts, and two linguists determine whether the resulting product is appropriate or feasible. After the resulting product was assessed as viable and valid by the expert, it was continued with a validation test on 30 elementary school teachers in Bogor Regency and became the basis for determining the final product. [19], [20].

Questionnaire instruments or non-test questions are used to validate the product with the answers provided in a checklist $(\sqrt{ })$. Besides, open interviews with experts were used. There were 20 questionnaire questions for material experts and media experts and 18 questions for linguists, while the test for teachers used 20 questions. The questionnaire instrument used had 5 answer choices, namely very feasible with a score of 5 , possible with 4 , entirelypossible with a score of 3 , less achievable with a score of 2 , and not viable with a score of 1 . To test the effectiveness of the booklet using multiple-choice questions 20 Problem. This test was carried out by grade III students of Kedunghalang 03 Elementary School in Bogor City, consisting of 29 students with 14 male students and 15 female students.

The results of the answers are then searched for the percentage of the feasibility level of the booklet media developed from the results of the assessment of material experts, media experts, linguists, small-scale tests, and large-scale tests using the following formula [21]:

$$
\mathrm{P}=\frac{\sum \quad \text { Score obtained }}{\text { Skor maksimal yang diharapkan }} \text { Score obtained } x 100 \%
$$

The results of the answers are then sought for the average and converted into an assessment statement to determine the quality and level of product validity in the form of booklet media can be seen in Table 1 below.

Table 1. Criteria for granting validity [22]

\begin{tabular}{lll}
\hline No. & Validity Criteria & Validity Level \\
\hline 1. & $04.01-05.00$ & Very valid and very decent, no need to revise \\
2. & $03.01-04.00$ & Valid and decent but needs a little revision \\
3. & $02.01-03.00$ & Quite valid, can be used but needs revision \\
4. & $01.01-02.00$ & Invalid, it is recommended not to use it because it needs a lot of revisions \\
5. & $00.00-01.00$ & Invalid - may not be used \\
\hline
\end{tabular}

\section{Results and Discussion}

The final product of this research is a media development booklet with a drop arrangement as follows: 1) the booklet is entitled "Prevention of Bullying for Elementary School Students", 2 ) uses the writing of time new romance with a writing size of $10 \mathrm{pt}, 3$ ) the number of pages consists of 24 pages with a height of $13.3 \mathrm{~cm}$, a width of $9.5 \mathrm{~cm}$ and a thickness of $2.03 \mathrm{~cm}, 4$ ) cover of the front, inside and back cover, 5) Contents consisting of 7 chapters, 6) introduction, 7) list contents, 8) Conclusions, and 9) bibliography. For the contents, chapter 1 contains an introduction. Chapter 2 contains the meaning of bullying, chapter 3 the impact caused by bullying, chapter 4 signs of being a victim of bullying, chapter 5 with the title so as not to bully, chapter 6 Attitudes and actions for bully handling, and chapter 7 penalties for bullies.

After the draft is made, it is then tested for validation by the experts. The results of the experts' assessment, from the material expert 1 test obtained a score of 81 with an average score of 4.05 and material expert 2 of a score of 87 with an average score of 4.35 from the two experts, 
the overall score was 168 with an average score in the range of 4.2 or around $84 \%$. Thus, the results of the material expert's validation are declared valid and very suitable for use, do not need to be revised. The results of the validation of the media expert 1 total amounted to 82 or the average score range 4.1 from the media expert 2 was 85 or the average score was 4.25 . The total number of media experts is 167 with an average score of 4.12 and is in the range of $82.4 \%$, so based on the table the criteria for giving the validity value of the results of the media booklet media experts are declared valid and very suitable for use, do not need to be revised. The validation results of linguist 1 is 67 or is at an average of 3.73, and linguist 2 is 71 or an average of 3.95. The two linguists' results obtained a total number of 138 or in the range of 3.84 or in the fieldof $76.6 \%$. Based on these two linguists, it is declared valid and feasible but needs a little revision. From all the experts, the overall score is obtained by an average of 4.06 so that the booklet according to the experts is declared valid and very suitable for use, it does not need to be revised. Although the experts stated that it was usefuland very relevantfor help, it did not need to be revised, but the experts provided input so that the title was more interesting, added verses and hadiths that prohibited bullying and the legal basis for bullying.

After being corrected and validated by experts, it was continued with a validation test by elementary school teachers in Bogor Regency, consisting of 30 teachers. The test validation assessment results by elementary school teachers obtained a total number of 2516 with an average of 83.87 and if converted at a score of 4.19 or in the range of $83.5 \%$. The test results from elementary school teachers mean that the booklet media is very suitable for use and does not need to be revised. The following is a recapitulation of the experts and teachers shown in Table 2 below.

Table 2. Results of validation recapitulation

\begin{tabular}{llllll}
\hline No & Validator & Amount & Average & Percentage & Criteria \\
\hline 1 & Material Expert & 168 & 4.2 & 84 & Valid and very decent \\
2 & Media Expert & 167 & 4.12 & 82.4 & Valid and very decent \\
3 & Linguist & 138 & 3.84 & 76.6 & $\begin{array}{l}\text { Valid and decent but needs a little } \\
\text { revision }\end{array}$ \\
& & & & & Valid and very decent \\
\hline
\end{tabular}

Based on table 2, the highest assessment is given by material experts and the lowest by linguists, however, all validators state that the booklet in preventing bullying behavior for lowgrade students is declared valid and suitable for use. The following is a graph of Figure 1 the results of the validation test from the experts. 


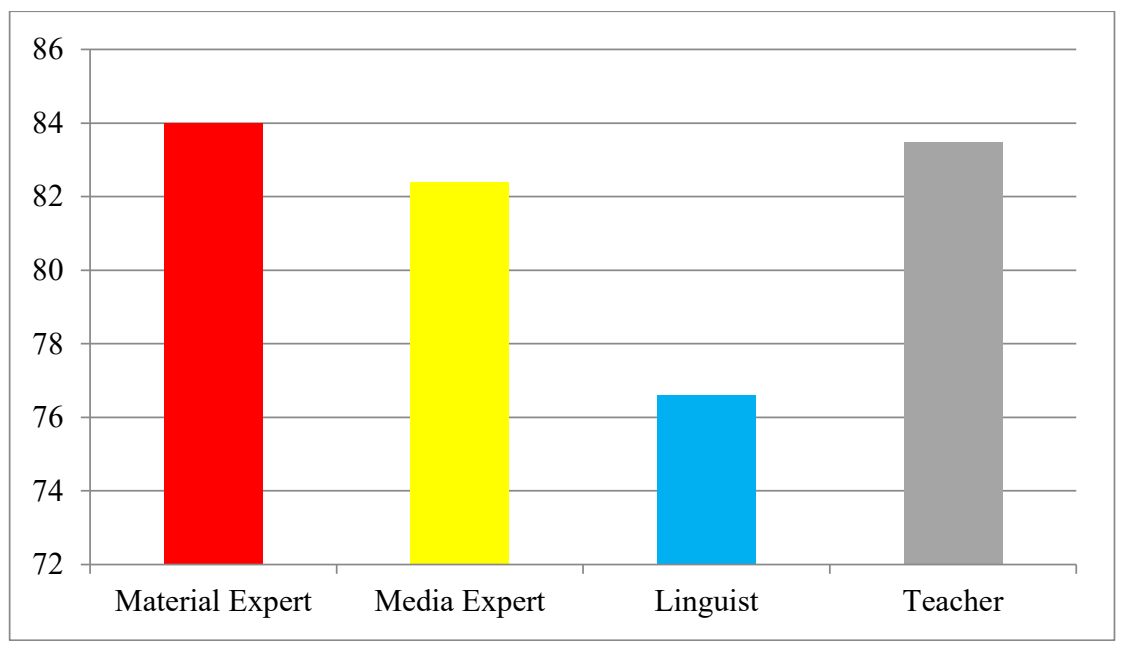

Fig. 1. Results of validation recapitulation

Based on the graph in Figure 1, the results of the experts and teachers show that the booklet media is declared practical and effective by considering the number of pages, design, color, type and size of letters, paper quality, message substance, and message content depth so that it is suitable for use.

Based on the experts and teachers' input, improvements were made by changing the cover colour to be more attractive, using language that was easier to understand, and adding pictures and photos about bullying behaviour and student delinquency. Following the booklet's revision, the title was changed to "Let's Make Friends" with the background of elementary school children lining up and a child who covers his face as a sign of shame and sadness. This title and made is made so that low-level school students feel interested in reading it. The inside cover contains the authors and the title, with pictures of elementary school students dancing traditional dances. This picture is intended so that elementary school students can look for positive activities. Still on the inside cover, plus a small inscription "To hurt a friend means to hurt yourself".

Furthermore, the foreword starting with pages $i$ and ii. The table of contents occupies page iii. The content of the booklet consists of six chapters, namely chapter 1 contains an introduction with pages 1 to 2, chapter 2 is given the title of what is bullying starting from pages 3 to 16 , pages 17 to 18 contents of chapter 3 about the impact of bullying, chapter 4 contains signs - sign of being a victim of bullying on pages 19 to 21 , chapter 5 contains bullying action handlers starting from pages 22 to 27 . Chapter 6 starts from page 28 to page 30 with material explaining the law of bullying. Conclusions are on pages 31 and 32. Pages 33 to 35 contain a bibliography. The last page of this booklet includes the verses and hadiths about bullying entitled the bullying perpetrator can be prosecuted in the afterlife. The previouspage contains the author's bio. The inscription is "Let's Make Friends Without Hurting" in small writing on the back cover.

Furthermore, the booklet's final product on prevention of bullying behaviour in low-grade elementary school students is made according to the level of practicality with a paper size of $14.5 \mathrm{~cm}$ high and $9.5 \mathrm{~cm}$ wide. Using Time New Roman writing in $10 \mathrm{pt}$ font, this is intended to make the writing easy to read. For this Booklet to be substantial, durable, and not easily damaged, the front and back covers use 410-gram art carton. For the contents, 150 grams of matt paper and laminating doof make it stick more firmly. This media booklet was developed 
using the Corel Draw 6 application. The following is a booklet image in preventing bullying behaviour in low-grade elementary school students shown in Figure 2.

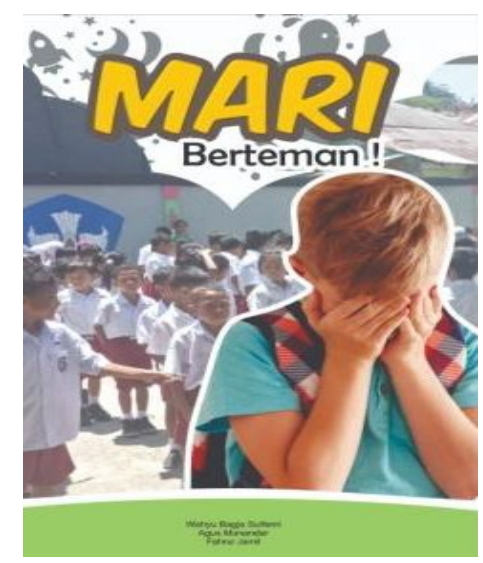

Front cover

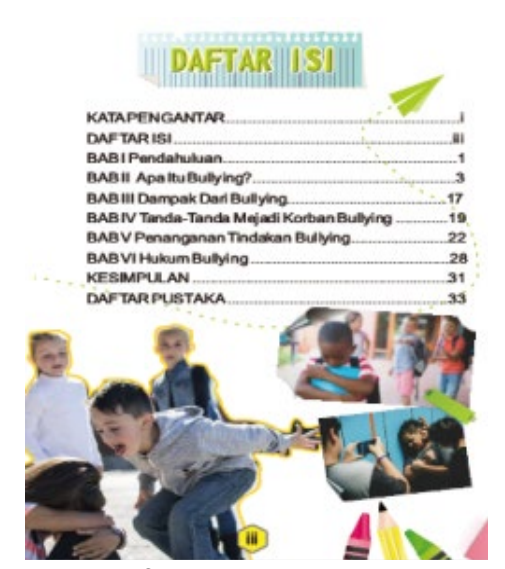

Table of contents booklet

Fig. 2. Display booklet

After the booklet media is finished, the booklet effectiveness test is carried out, which is the final stage. At this stage, 20 multiple choice questions were used for grade 3 students at Kedunghalang 03 Elementary School Bogor City, totalling 29 male students 15 and 14 female students. However, before the booklet is tried out, first test the knowledge and understanding of students' initial understandingof bullying behaviour. Based on the questions given after being examined, the total score was 1640 , the highest score was 85 , the lowest score was 25 , the average was 56.55 , and the students who reached the predetermined score were ninestudents or $31.03 \%$.

After knowing the understanding test, testing the effectiveness of the booklet's use on lowgrade elementary school students. This activity is carried out like learning activities in the preliminary test, but at this stage, the students are divided into several groups and given booklets to be read and understood to be discussed with their groups. The discussion was conducted to see to what extent booklets' effectiveness when used in arguments. The implementation results obtained an overall score of 2360, the highest score of 100, the lowest score of 55, an average of 81.38 , and students who reached the predetermined value were 21 students or $72.41 \%$. The comparison of students' understanding after and before using the booklet media can be seen in Table 3 below [23].

Table 3. Comparison of the results of student understanding before and after the use of booklet

\begin{tabular}{lllllll}
\hline & $\begin{array}{l}\text { Amount } \\
\text { Values }\end{array}$ & $\begin{array}{l}\text { The highest } \\
\text { score }\end{array}$ & $\begin{array}{l}\text { Lowest } \\
\text { Value }\end{array}$ & Average & $\begin{array}{l}\text { Number } \\
\text { students }\end{array}$ & of Percentage \\
\hline Pre-Test & 1640 & 85 & 25 & 56.55 & 9 & 31.03 \\
Post-Test & 2360 & 100 & 55 & 81.38 & 21 & 72.41 \\
\hline
\end{tabular}

Based on Table 3, a comparison diagram can be made between students' initial understanding and after using booklet media which has experienced a significant increase. The following is a comparison diagram which is presented in the diagram in Figure 2. 


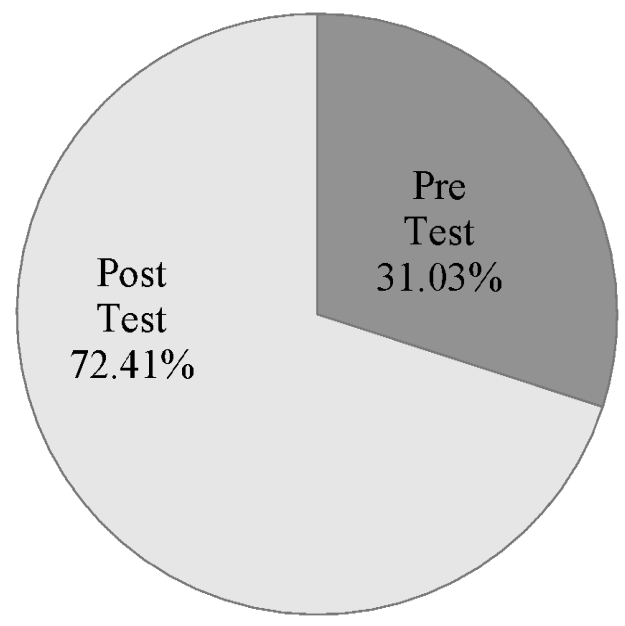

Fig. 3. Comparison of students' initial understanding after using the booklet

Based on the diagram in Figure 3, students' understanding of bullying at the beginning was very low, amounting to only 31.03 percent, while after being given learning using booklet media, it increased to $72.41 \%$. Thus, this booklet media is very suitable for low-grade students who try between 6 or 7 to 8 or 9 years.

Based on the validation results from experts, teachers, and practicality and effectiveness tests, it is suitable for use. The results of this study are also following research from Gemilang\& Christiana.Febriani\&Winingsih'sanalysis that the media booklet developed for students is expected to: 1) provide alternatives in preventing bullying, 2) to find solutions to prevent bullying, 3) to cut eyes chain of perpetrators and a culture of bullying, 4) to anticipate acts of violence in schools by students, 5) to increase students' sense of concern for their environment, 6) a form of intervention to bullies that bully behaviour is behaviour that is not justified, 7) this approach reintegrates students who have made mistakes into the school community to make students who obey and obey the rules and values, and 8) make the school a safe and comfortable place for students. [24]. [25]

The use of booklet media follows the character of low-grade elementary school students in learning, namely 1) concrete, low-grade elementary school students, one of its characteristics is learning from concrete things and gradually moving towards an abstract one with photos in the booklet. , 2) Integrative, namely with this booklet media, elementary school students of low grade children still see something as a whole, they cannot separate a concept into parts, 3) Hierarchical, this booklet media makes children's learning methods develop gradually from simple things to more complex things, 4) The use of booklet media in serious but relaxed learning makes learning while playing because at this age students still like to play, 5) Booklet media that can be used in group learning will make students who still enjoy learning with their friends, and 6) Media booklet this makes students of this age-sensitive and rapid to imitate because there are examples or from photographs or images contained in booklets [26], [19].

With the use of this booklet media, low-grade elementary school students have morality when interacting with their peers, can consider other people's feelings when making decisions because moral cultivation is carried out without the students realizing it. Thus, it can encourage self-awareness to act with good morals so that bullying does not happen again. 


\section{Conclusion}

Based on research on the development of a model for overcoming bullying behaviour in schools based on booklet media, it can be concluded as follows: 1) The results of the validation from the material, media, and language experts show that the booklet developed meets valid criteria and is suitable for use. 2) The results of the validation test by elementary school teachers in Bogor Regency which consisted of 30 booklet teachers were very feasible to use and did not need to be revised, 3) The results of large-scale trials for grade 3 students at Kedunghalang 03 Elementary School in Bogor City showed that the media booklet is valid and feasible to use. 4) Thus, this booklet media can be used as an early prevention of bullying deviant behaviour.

Based on the above conclusions, several things should be done: 1) That such studies should be carried out with a broader sample with various school levels. 2) Various delinquency of students must be taken as early as possible, especially since elementary school. 3) With this booklet media, the researcher recommends continued in the broader study such as drugs, free sex, and others.

\section{Acknowledgement}

This study would not have been carried out without several parties forming it. Therefore, the authors would like to thank the observers from Bismas 2020, LPPM STKIP Muhammadiyah Bogor, Head of the West Java Language Center, Principal of SDN Kedunghalang 3 Bogor City Mrs Eti Kurniati, S. Pd.

\section{References}

[1] S. Sufriani and E. P. Sari, "Faktor yang Memengaruhi Bullying pada Anak Usia Sekolah di Sekolah Dasar Kecamatan Syiah Kuala Banda Aceh,” Idea Nurs. J., vol. 8, no. 3, pp. 1-10, 2017, [Online]. Available: http://jurnal.unsyiah.ac.id/INJ/article/view/9678.

[2] W. B. Sulfemi, "Pengaruh Disiplin Ibadah Sholat, Lingkungan Sekolah, dan Intelegensi terhadap Hasil Belajar Peserta Didik Mata Pelajaran Pendidikan Agama Islam," EDUKASI J. Penelit. Pendidik. Agama dan Keagamaan, vol. 16, no. 2, pp. 166-178, 2018, doi: 10.32729/edukasi.v16i2.474.

[3] H. M. Isman, "Fenomena Bullying Antar Siswa," J. PIPSI (Jurnal Pendidik. IPS Indones., vol. 4, no. 1, p. 25, 2019, doi: 10.26737/jpipsi.v4i1.1237.

[4] Wiwit Viktoria Ulfah, S. Mahmudah, and R. M. Ambarwati, "Fenomena School Bullying yangTak Berujung," J. Psikol. Ilm., vol. 44, no. 12, pp. 2-8, 2019, doi: DOI: 10.15294/intuisi.v9i2.11608.

[5] W. B. Sulfemi and O. Yasita, "Dukungan Sosial Teman Sebaya Terhadap Interaction of Peer' S Sosial Support and," Pendidikan, vol. 21, no. 2, pp. 133-147, 2020, doi: https://doi.org/10.33830/jp.v21i2.951.2020.

[6] D. Darmawan, "Bullying Phenomena in School Setting," J. Pendidik., vol. 1, no. 2, pp. 253-262, 2017, doi: https://doi.org/10.21831/jk.v1i2.9713.

[7] E. Amalia, L. Nurbaiti, W. S. Affarah, and H. Kadriyan, "Skrining dan Edukasi Pencegahan Bullying Pada Siswa SMA Negeri Di Kota Mataram,” J. Pengabdi. Magister Pendidik. IPA, vol. 1, no. 2, 2019, doi: 10.29303/jpmpi.v1i2.245. 
[8] N. Dewi, H. Hasan, and M. AR, "Perilaku Bullying yang Terjadi di SD Negeri Unggul Lampeuneurut Aceh Besar,” J. Ilm. Pendidik. Guru Sekol. Dasar, vol. 1, no. 2, pp. 37-45, 2016, [Online]. Available: http://www.jim.unsyiah.ac.id/pgsd/article/view/1802/1014.

[9] I. Eldiorita and Layyinah, "Effect of social competence and school stress on bullying behavior in adolescent," Tajkiya J. Psikol., vol. 4, no. 1, pp. 1-11, 2016, doi: DOI: 10.15408/tazkiya.v4i1.10824.

[10] I. Z. Arofa, H. Hudaniah, and U. Zulfiana, "Pengaruh Perilaku Bullying terhadap Empati Ditinjau dari Tipe Sekolah,” J. Ilm. Psikol. Terap., vol. 74, no. 4, pp. 55-61, 2018, doi: https://doi.org/10.22219/jipt.v6i1.5435.

[11] I. Victorynie, "Mengatasi Bullying Siswa Sekolah Dasar Dengan Menerapkan Manajemen Kelas Yang Efektif," Pedagogik, vol. V, no. 1, pp. 28-41, 2017, doi: Vol 5 No I (2017): PEDAGOGIK: Jurnal Pendidikan Guru Sekolah Dasar.

[12] E. S. Papacosta, A. Paradeisioti, and C. Lazarou, "Bullying Phenomenon and Preventive Programs in Cyprus's School System,” Int. J. Ment. Health Promot., vol. 16, no. 1, pp. 67-80, 2014, doi: 10.1080/14623730.2014.888894.

[13] W. B. Sulfemi, "Model Pembelajaran Contextual Teaching And Learning (CTL) Berbantu Media Miniatur Lingkungan Untuk Meningkatkan Hasil Belajar IPS,” Edunomic J. Pendidik. Ekon., vol. 7, no. 2, p. 73, 2019, doi: 10.33603/ejpe.v7i2.1970.

[14] T. F. Arsyad Arsyad, Wahyu Bagja Sulfemi, "Penguatan Motivasi Shalat dan Karakter Peserta Didik Melalui Pendekatan Pembelajaran Kontekstual Pada Mata Pelajaran Pendidikan Agama Islam," Potensia J. Pendidik. Islam, vol. 6, no. 2, pp. 185-204, 2020, doi: http://dx.doi.org/10.24014/potensia.v6i2.9662.

[15] N. H. Dewi Apriani Fr, Dewi Amaliah Nafiati, "Sistem Pembelajaran di Sekolah Dasar Kelas Rendah Berbasis Paikem Gembrot Guru SD di Kecamatan Kramat Kabupaten Tegal,” J. Penelit. Dan Wacana Pendidik., vol. 10, no. 1, pp. 16-29, 2016, [Online]. Available: https://garuda.ristekbrin.go.id/documents/detail/1884413.

[16] W. B. Sulfemi and N. Mayasari, "The Use of Audio Visual Media in Value Clarification Technique to Improve Student Learning Outcomes in Social Studies," J. Pendidik., vol. 20, no. 1, pp. 53-68, 2019, doi: https://doi.org/10.33830/jp.v20i1.235.2019.

[17] N. Ningrum, R. Ambarwati, and E. Sulistyowati, "Pengaruh Konseling Gizi Dengan Media Booklet Terhadap Konsumsi Sayur Buah Dan Fast Food Pada Remaja Obesitas,” J. Ris. Gizi, vol. 7, no. 2, pp. 115-119, 2019, doi: 10.31983/jrg.v7i2.5150.

[18] W. B. Sulfemi, "Pengaruh Rasa Percaya Diri Dan Gaya Kepemimpinan Kepala Sekolah Terhadap Kinerja Guru," Nidhomul Haq J. Manaj. Pendidik. Islam, vol. 5, no. 2, pp. 157-179, 2020, doi: $10.31538 /$ ndh.v5i2.557.

[19] H. Irawati, A. Kartini, and S. A. Nugraheni, "Pengaruh Booklet terhadap Pengetahuan dan Sikap Kesehatan Reproduksi Calon Pengantin Terkait Pencegahan Risiko Kehamilan di Kabupaten Pemalang,” J. Manaj. Kesehat. Indones., vol. 7, no. 2, pp. 124-131, 2019, doi: https://doi.org/10.14710/jmki.7.2.2019.124-131.

[20] F. Muhammad, P. Muhiddin, and Adnan, "Pembelajaran Arthropoda Menggunakan Booklet Sebagai Sumber Belajar Mandiri Siswa Kelas X SMA/MA,” Biol. Teach. Learn., vol. 1, no. 1, pp. 28-32, 2018, [Online]. Available: https://ojs.unm.ac.id/btl/article/view/7546.

[21] H. Setiawan and H. A. K. Wardhani, "Pengembangan Media E-Booklet pada Materi Keanekaragaman Jenis Nepenthes,” EDUMEDIA J. Kegur. dan Ilmu Pendidik., vol. 3, no. 2, p. 92, 2019, [Online]. Available: http://jurnal.unka.ac.id/index.php/fkip/article/view/176.

[22] S. Purnama, "Metode Penelitian Dan Pengembangan (Pengenalan Untuk Mengembangkan Produk Pembelajaran Bahasa Arab)," LITERASI (Jurnal Ilmu Pendidikan), vol. 4, no. 1, p. 19, 2016, doi: 10.21927/literasi.2013.4(1).19-32.

[23] N. Putra, Research \& Development Penelitian dan Pengembangan: Suatu Pengantar, First edit., vol. 4, no. 2. Jakarta: PT Raja Grafindo Persada, 2017.

[24] R. Gemilang and E. Christiana, "Pengembangan Booklet Sebagai Media Layanan Informasi Untuk Pemahaman Gaya Hidup Hedonisme Siswa Kelas Xi Di Sman 3 Sidoarjo,” Pendidikan, pp. 3-9, 2015, [Online]. Available: https://jurnalmahasiswa.unesa.ac.id/index.php/jurnal-bkunesa/article/view/15890. 
[25] S. G. Febriani, "Pengembangan Media Booklet Melalui Layanan Informasi dalam Upaya Pencegahan Perilaku Bullying di SMAN 7 Surabaya,” J. UNESA, vol. 8, no. 2, pp. 43-50, 2016, [Online]. Available: https://jurnalmahasiswa.unesa.ac.id/index.php/jurnal-bkunesa/article/view/23148.

[26] K. H. K. Darmayanti, K. Farida, and D. D. D. Situmorang, "Bullying di sekolah: Pengertian, Dampak, Pembagian dan Cara Menanggulanginya," Pedadogya J. Ilmu Pendidik., vol. 17, pp. 5566, 2019, [Online]. Available: https://ejournal.upi.edu/index.php/pedagogia/article/view/13980. 